DOI: $10.20472 /$ IAC.2019.052.016

\author{
JACOBUS JOHANNES DE JONGH \\ North-West University , South Africa \\ PRECIOUS MNCAYI \\ North-West University, South Africa
}

\title{
AN ANALYSIS OF THE FACTORS AFFECTING DISCOURAGEMENT IN SOUTH AFRICA'S LABOUR MARKET
}

\begin{abstract}
:
In recent years, labour markets across the world have been characterised by instability and insecurity, with employment being scarce. Even though the 21st century has brought with it technological change and a rise in the importance of education for better employment prospects, it has likewise resulted in increased uncertainty which has failed to guarantee employment for work-seekers. For those who want to work, the failure to secure employment has been a source of enormous hardships both personally and economically. This is not unique to South Africa as the country is plagued with very high unemployment rates and a unique case of a significant amount of discouragement amongst its work-seekers. Whilst unemployment indicators have largely followed international standards, the failure to incorporate those who have abstained from searching has inadvertently contributed to a lack of understanding regarding the nature of discouragement in the labour market. Against this background, using data collected through the 2019 Quarterly Labour Force Survey, the study analyses the impact of several factors that influence discouragement in the South African labour market. A quantitative and cross-sectional research design was employed while descriptive statistics, cross-tabulations and a binary logistic regression were used to analyse the data. The findings indicate that discouragement is influenced by a myriad of factors which point to the poor health of the labour market. In particular, a low absorption capacity, structural mismatches and the use of ineffective and ill-informed job-search methods all contributed to the likelihood of abnegation in job search activity. Moreover, various demographic variables such as age, race and geographical location were found to be significant predictors, reflecting the impact of various labour market inequalities that have deterred the progress in improving labour market outcomes. The results in this regard, carry imperative implications towards the comprehension of the dynamics surrounding the functioning of labour markets, especially from a developing context. In addressing the situation, a drastic shift in policy formulation directed towards the labour market as well as the creation of sustainable inclusive growth is recommended. This should include the relaxation of labour market regulations and the creation of enabling environments for the private sector that can assist in the establishment of sustainable employment opportunities. Moreover, strategies directed towards the development of quality labour market services such as intermediation, the provision of public works programmes and job search assistance should be proliferated in order to improve the jobseeker-employer matching process.
\end{abstract}

\section{Keywords:}

Discouragement; work-seekers, labour markets, South Africa, unemployment.

JEL Classification: J01, J21, 015 